\title{
大卒女性の結婚年齢に関する研究
}

\section{Analysis of Female University Graduates' Marriage Age}

\section{中 村三 緒子 \\ NAKAMURA Mioko}

The purpose of this article is to establish the effect of female university graduates' professional situation on marriage decision. In this perspective and to reveal the determinants of marriage decision I made four hypotheses and verified them by analyzing the result of a questionnaire survey. This questionnaire survey was conducted on female university graduates who graduated co-educational universities or women's universities (career colleges, liberal arts colleges, or both) aged from 28 to 38 in 2001.

The main findings were as follow: women who cannot establish a secured professional position postpone their marriage; women's social and professional independence has a direct effect on their marriage willingness. Consequently, it has become necessary to establish a policy that enables a stable professional career situation for these women.

\section{1 ． 課題の設定}

本研究の目的は、大卒女性の職業と結婚年齢との関係を明らかにすることである。

近年女子の大学進学率が上昇し、大卒女性が増加している。高学歴の女性ほど晚婚化の 傾向がある（脇坂 2001）。女性の晚婚化要因として、女性の高学歴化、専門職従事者の 増加と相まった価值観の変化があげられる（阿藤 1991，1997など）。しかし、『第10回出 生動向基本調査』の個票データ（未婚者と既婚者）を用いて結婚年齢と職業との関係を検 討した小島（1994）は、結婚前の職業が臨時・無職、自営業の場合に結婚年齢を遅らせる 傾向を示した。これらの結果から女性の結婚前の職業と結婚年齢との関係は一定ではな w。

また、『第10回出生動向基本調査』の個票（夫婦票と独身者票）を用いて、20-34歳女性 の結婚年齢に与える影響を分析した阿部（1999）は、学卒直後の失業率が低い世代では結 婚が遅く、失業率が高い世代では結婚が早いことを指摘した。阿部によると、学卒時に良 い条件の仕事に就いた場合、就業期間が長くなり結婚年齢が高くなるという。世代ごとに 学卒時の労働市場の状態が就業行動と結婚年齢を規定する可能性がある。

以上の課題に対して、本研究は年齢層別に職業と結婚年齢との関係を検討する。女性の 高学歴化の影響により新規学卒就職者数は大卒が高卒を上回り（労働省 2000）、結婚年 齢が高いとされる専門技術職従事者には高学歴者が他の学歴に比べて多い。従来の研究で は、大卒女性の結婚年齢が高いことは指摘されてきたものの、大卒女性の職業と結婚年齢 との関係は十分に明らかにされているとはいえない。本研究では、大卒女性の結婚年齢と 職業との関係を明らかにすることを試みる。 


\section{2. 先行研究の検討}

女性の晩婚化に関する説明は、これまで「専門職晚婚仮説」、「パラサイト・シングル仮 説」、「育児・休業制度に注目した研究」、「ジェンダー・トラック仮説」などがあげられて きた。

\section{1 専門職晚婚仮説}

職業と結婚年齢との関係は、SSM調査や出生調査データを用いて検討されてきた。渡 辺・近藤（1990）は、1985年のSSM女性調査デー夕を用いて結婚時の職業が専門・管理及 び事務・販売の者が晚婚であることを明らかにした。渡邊（1993）は、『第10回出生動向 基本調査 (夫婦調査)』データを用いて結婚年数を15年以内に限定し、専門・管理職の平 均初婚年齢が最も高いことを指摘した。岩澤（1998）は、『第11回出生動向基本調査』デ ー夕（夫婦調査）を用いて年齢を30-49歳に限定し、自営業・家族従業と正規雇用の結婚 年齢が高いことを示した(1)。すなわち、晚婚女性は正規の職員で、かつ専門・管理職の者 である。

\section{2 パラサイト・シングル仮説}

山田によると、パラサイト・シングルは学卒後もなお、親と同居し、生活のためのコス トや身の回りの家事を親に負担してもらい、付加的消費のみ自分が出す未婚者のことであ る（山田 1996、1999）。パラサイト・シングルは、結婚・独立して生活水準が低下する より、親と同居して高い生活水準を維持することを選択する。パラサイト・シングルの増 加が未婚化・晚婚化を促進する。

\section{3 育児・休業制度に注目した研究}

女性の就業・結婚行動に法制度、特に育児休業制度の影響が検討されてきた。滋野・大 日（1998）は、パネル調査（1993年と1994年）の個票データから育児休業制度は就業継続 を促進させるが、結婚を選択するか否かには影響を与えないことを指摘した。一方、桶口 （1994）は、1987年の「就業構造基本調査」を用いて、育児休業制度の企業規模別普及率 と婚姻との関係を分析し、育児休業制度は就業による結婚阻害要因を和らげる効果がある ことや特に高学歴層に効果が大きいことを明らかにした。

\section{4 ジェンダー・トラック仮説}

学校教育は女性の性役割観やライフコース展望に影響を与えると指摘されてきた（中西 1998)。女子大学生を対象に調査した中西（1998, 111-147頁）は、大学の特徽から女子大学 にはキャリア女性の養成を目的とした教育がなされている職業系女子大学、教養女性の養 成を目的とした教育がなされる教養系女子大学、両グループの中間的特徵をもつ中間的女 子大学が存在することを示した。職業系女子大学の学生には、より威信の高い職業への就 職や長期間就業を希望し、職業と家庭の両立を希望する者が多い。一方、教養系女子大学 の学生は、より短期間の就業や家庭・育児優先的なライフコースを希望する者が多い。中 間的女子大学の特徵は、職業系女子大学の学生の志向と教養系女子大学の学生の志向をも つことである。具体的には、職業選択で重視する事柄は職業系女子大学の学生と類似の傾 向を示すものの、配偶者に希望する事柄は教養系女子大学の学生と類似する。また、職業 
系女子大学の学生と同様に、職業と家庭の両立を希望する者が多い。

\section{3. 研究の枠組み}

本研究は、大卒女性を対象にした調査デー夕(2)に基づいて、各仮説を検証し、大卒女性 の結婚年齢の規定要因を明らかにする。

\section{1 調査の対象}

1) 使用データ

2001年 1 月と2001年12月(3)に大卒女性を対象に実施した質問紙郵送調査 ${ }^{(4)}$ に基づいてい る。

2) 調査対象者の出身大学

首都圈(5)の四年制女子大学 7 校と四年制共学大学 10 校(6)を対象とした。女子大、共学大 それぞれの偏差值は45-67に該当する(7)。

\section{2 対象者の属性}

1) 対象者の年齢

本研究は未婚期の職業が結婚年齢に与える影響に注目するため、対象者は(1)平均初婚年 齢以上 $(27.4$ 歳(8) 代とした。すなわち、1986-1996年に大学を卒業した28-38歳の女性である。

2) 平均初婚年齢

本研究の対象者の平均結婚年齢は27.3歳で、『第11回出生動向基本調査』（1998年）と同 様の結果である。

3) 対象者本人の従業上の地位、職種、居住形態

『第11回出生動向基本調査』（1998年）の「結婚直前の従業上の地位と職種」および 『第11回出生動向基本調查』(1999年）の「独身者の母親との同別居」(9) と比較して、本研 究の対象者の従業上の地位と職種、親との同別居は変わらない（表 $1-1$ 、表 $1-2$ 、表 1 3 )。

4) 対象者の両親の属性

本研究の対象者の両親は、『第11回出生動向基本調査』（1999）と『国勢調査』（2000） と比較して高階層の者が多い（表 1 - 4、表 1 - 5、表 1 - 6)。

表 $1-1$ 本人従業上の地位

単位: $\%$

\begin{tabular}{|c|c|c|}
\hline & 本調査 & 出生調査 \\
\hline 正規の職員 & 82.1 & 81.9 \\
パート・阬仆 & 6.9 & 7.5 \\
派遣・契約社員 & 3.9 & \\
自営業·家族従業者 & 1.6 & 3.0 \\
その他 & 1.4 & 2.6 \\
無職 & 2.8 & 3.9 \\
不詳 & 1.2 & 1.0 \\
\hline
\end{tabular}

表 1 - 2 本人職種

単位: \%

\begin{tabular}{|c|c|c|}
\hline & 本調査 & 出生調査 \\
\hline 経営·管理職 & 1.3 & 0.4 \\
\hline 事務職 & 47.4 & 45.8 \\
\hline 教育職 & 11.2 & \\
\hline 専門·技術職 & 23.3 & 21.5 \\
\hline 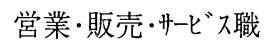 & 12.8 & 21.9 \\
\hline 工場などの現場労働 & 0.1 & 7.7 \\
\hline その他 & 2.7 & 1.0 \\
\hline 不祥 & 1.3 & 1.7 \\
\hline
\end{tabular}


表 1 - 3 本人居住形態

単位: \%

\begin{tabular}{|c|c|c|}
\hline & 本調査 & 出生調査 \\
\hline 同居 & 81.7 & 74.4 \\
ひとり暮らし & 18.1 & 24.9 \\
不詳 & 0.1 & 0.7 \\
\hline
\end{tabular}

表 1 - 4 父親学歴

単位: $\%$

\begin{tabular}{|c|c|c|c|}
\hline & 本調査 & 出生調査 & 国勢調査 \\
\hline 新制中・旧制高小・旧制小 & 5.5 & 20.1 & 42.2 \\
新制高校・旧制中学 & 22.0 & 46.4 & 38.3 \\
短大·高専 & 2.4 & 3.8 & 2.3 \\
旧制高・旧制専門学校 & 3.7 & & \\
大学・大学院 & 64.8 & 23.3 & 13.5 \\
その他 & 0.4 & 0.7 & 0.2 \\
不詳 & 1.4 & 5.8 & \\
\hline
\end{tabular}

表 1 - 5 父親職種

単位: \%

\begin{tabular}{|c|c|c|}
\hline & 本調査 & 出生調査 \\
\hline 経営·管理職 & 46.7 & 23.0 \\
事務職 & 6.0 & 7.8 \\
専門·技術職 & 24.3 & 18.9 \\
営業·販売·サービス職 & 9.2 & 16.9 \\
工場などの現場労働 & 3.0 & 15.7 \\
その他 & 5.6 & \\
無職 & 2.4 & \\
不祥 & 2.7 & 6.6 \\
\hline
\end{tabular}

表 1-6 母親学歴

単位: \%

\begin{tabular}{|c|c|c|c|}
\hline & 本調查 & 出生調査 & 国勢調查 \\
\hline 新制中 ·旧制高小·旧制小 & 6.5 & 22.3 & 41.8 \\
新制高校・旧制女学校 & 48.4 & 54.7 & 46.5 \\
短大·高専 & 16.1 & 12.6 & 5.3 \\
旧制専門学校 & 5.2 & & \\
大学·大学院 & 21.6 & 5.0 & 2.5 \\
その他 & 0.7 & 0.7 & 0.2 \\
不詳 & 1.4 & & \\
\hline
\end{tabular}

出所：出生調査一『第11回 出生動向基本調査』(1998, 1999)

国勢調査一『国勢調査』(2000)

注: 出生調査の両親結果は、35歳未満独身者の両親に関する結果、

対象者の父親の平均出生年は1934年、母親出生年は1938年である。 そのため、『国勢調査』は父親65-69歳層、母親60-64歳層を参照した。 各調査において、該当しない項目の数值は空闌にした。

本調査 N=1394。ただし、表1-2 N=1356。 


\section{3 年齢層と結婚年齢集団の設定}

\section{1)年齢層の設定}

学卒時の労働市場の状態によって世代ごとの就業行動と結婚年齢が規定される可能性 （阿部 1999）から、対象者を年齢層別に区分した。大卒女子の求人倍率と景気の影響を 考慮して、3つの年齢層を設定した。第 1 に1989年以前に大学を卒業した世代、第 2 に 1990-1993年に大学を卒業した世代、第 3 に1994年以降に大学を卒業した世代とした。す なわち、35-38歳層（1989年以前大学卒業）、31-34歳層（1990-1993年大学卒業）、28-30歳 層（1994以降大学卒業）である。

2)結婚年齢集団の設定

従来の結婚行動に関する研究は、既婚者を対象とするものが多い。これらの研究には、 年齢等の限定を加えない限り比較的早婚者が多く、晚婚者の少ない偏ったサンプルを分布 する可能性があるといった問題があった（小島 1990)。このような課題に対して、本研 究では結婚年齢集団別の分析を行った。対象者の年齢は28-38歳であり、若年者には早婚 者が多く、高年齢者には早婚者と晚婚者が含まれる。また、早婚者と晚婚者を一括した分 析では、職業に対する年齢の影響が分析結果を歪める可能性もある。このような年齢の影 響を除くため、平均初婚年齢を基準に 3 つの結婚年齢集団を設定した。

第 1 に平均初婚年齢より前に結婚した者、第 2 に平均初婚年齢（27歳）前後 1 歳で結婚 した者、第 3 に平均初婚年齢より後に結婚した者である。すなわち、25歳以下で結婚した 者（早婚者）、26-28歳で結婚した者（平均初婚年齢で結婚した者）、29歳以降に結婚した 者（晚婚者）である。なお、他の年齢の設定も可能であったが、分析の結果に大差がなか ったので、紙幅の関係上この 3 グループの分析結果を以下に述べることとした。

年齢層と結婚年齢集団の組み合わせは以下の通りである。

(1)28-30歳層：25歳以下で結婚、26-28歳に結婚、29歳以降に結婚

(2)31-34歳層：25歳以下で結婚、26-28歳に結婚、29歳以降に結婚

(3)35-38歳層：25歳以下で結婚、26-28歳に結婚、29歳以降に結婚

\section{4 変数の設定}

1)専門職晚婚仮説より

結婚年齢と職業との関係では、専門・管理職、事務・販売職の結婚年齢が高いこと、臨 時・無職、自営業の結婚年齢が高いことが指摘されている。先行研究の知見を整理して、 「職業」(「経営・管理・専門・教育」(以下「経営·専門職」)、「事務・販売」「派遣・ア ルバイト・無職・自営他」(以下「派遣・無職」) をを設定した。

2)パラサイト・シングル仮説より

親と同居する大卒女性は、経済面と生活面を親に依存し、豊かな生活を維持することを 望むため、結婚を遅らせると考えられる。パラサイト・シングル仮説を検証するため、 「居住形態」(「親と同居」「ひとり暮らし」) を設定した。

3)育児・休業制度仮説より

産休・育児休業制度が充実していれば、仕事を継続しやすいので、結婚・出産を促進さ せると考えられる。また、大企業勤務の方が中小企業勤務に比べて結婚年齢が若干高いこ とも指摘されている（樋口 1994）。企業規模と産休・育児休業制度との関連を検討する 
ため「育休制度」(「大企業(10)で制度が充実」「中小企業(11)で制度充実」「育休制度充実 していない」）を設定した(12)。

4)ジェンダー・トラック仮説より

職業系女子大学の学生は長期間就業を希望する者が多く、結婚よりも職業への志向性が 高いことから、職業系女子大出身者は結婚を遅らせると考えられる。一方、教養系女子大 学学生は、短期間の就業や家庭・育児優先のライフコースを希望する者が多いことから、 教養系女子大出身者は早く結婚すると考えられる。そこで、女子大学の効果を検証するた め、「大学」(「職業系女子大学」、教養系女子大学」「「中間系女子大学」、「共学大学」) を 設定した。

\section{4. 分析結果 ${ }^{(13)}$}

\section{1 年歯層別の結婚年齢と各仮説との関係}

年齢層別に結婚年齢と各仮説との関係をみると、(11994-1996年に大学を卒業した28-30 歳層は「育休制度」のみが有意であり、「大企業で制度が充実していた場合」、「中小企業 で制度が充実していた場合」「育休制度が充実していない場合」それぞれ26-28歳で結婚 した者が多い（表 2-1）。

(2)1990-1993年に大学を卒業した31-34歳層は「職業」のみが有意であり、「経営・尃門 職」と「事務・販売職」は26-28歳で結婚した者が多い（表 $2-2$ )。また、「派遣・無職」 は、26-28歳と29歳以降に結婚した者が多い。

(3)1986-1989年に大学を卒業した35-38歳層の結婚年齢と各仮説との関係は、「職業」、 「育休制度」「大学」が有意であった（表 $2-3$ )。「職業」においては「経営・尃門職」と 「事務・販売職」は26-28歳で結婚した者が多く、「派遣・無職」は、29歳以降に結婚した 者が多い。「育休制度」では、「大企業で制度充実していた場合」と「制度充実していない 場合」は26-28歳、「中小企業で制度が充実していた場合」は、29歳以降に結婚した者が多 い。「大学」は「職業系女子大学」出身と「中間系女子大学」出身は26-28歳で結婚した者 が多い。「教養系女子大学」出身と「共学大学」出身は、29歳以降に結婚した者が多い。

表2-1結婚年歯と各仮説との関係（現在年歯：28-30歳層）

\begin{tabular}{|c|c|c|c|c|}
\hline \multicolumn{2}{|c|}{ 仮説 $\quad$ 結婚年齢 } & 25歳以下 & 26-28歳 & 29歳以上 \\
\hline $\begin{array}{l}\text { 職 } \\
\text { 業 }\end{array}$ & $\begin{array}{c}\text { 経営·専門・教育 }(\mathrm{n}=40) \\
\text { 事務·販売 }(\mathrm{n}=94) \\
\text { 派遣・バイト・無職 }(\mathrm{n}=28)\end{array}$ & $\begin{array}{l}25.0 \\
26.6 \\
28.6\end{array}$ & $\begin{array}{l}57.5 \\
61.7 \\
64.3\end{array}$ & $\begin{array}{r}17.5 \\
11.7 \\
7.1\end{array}$ \\
\hline $\begin{array}{l}\text { 居 } \\
\text { 焦 } \\
\text { 形 } \\
\text { 態 }\end{array}$ & $\begin{array}{l}\text { 親と同居 } \quad(n=136) \\
\text { ひとり暮らし }(n=26)\end{array}$ & $\begin{array}{l}28.7 \\
15.4\end{array}$ & $\begin{array}{l}60.3 \\
65.4\end{array}$ & $\begin{array}{l}11.0 \\
19.2\end{array}$ \\
\hline $\begin{array}{l}\text { 育 } \\
\text { 休 } \\
\text { 制 } \\
\text { 度 }\end{array}$ & $\begin{array}{c}\text { 大企業・育休充実 }(n=56) \\
\text { 中小・育休充実 }(n=22) \\
\text { 制度充実していない }(n=78)\end{array}$ & $\begin{array}{l}21.4 \\
40.9 \\
24.4\end{array}$ & $\begin{array}{l}73.2 \\
40.9 \\
59.0\end{array}$ & $\begin{array}{r}5.4 \\
18.2 \\
16.7\end{array}$ \\
\hline $\begin{array}{l}\text { 大 } \\
\text { 学 }\end{array}$ & $\begin{array}{l}\text { 職業系女子大 }(\mathrm{n}=19) \\
\text { 教養系女子大 }(\mathrm{n}=8) \\
\text { 中間系女子大 }(\mathrm{n}=96) \\
\text { 共学大 }(\mathrm{n}=39)\end{array}$ & $\begin{array}{l}26.3 \\
25.0 \\
24.0 \\
33.3\end{array}$ & $\begin{array}{l}42.1 \\
62.5 \\
65.6 \\
59.0\end{array}$ & $\begin{array}{r}31.6 \\
12.5 \\
10.4 \\
7.7\end{array}$ \\
\hline
\end{tabular}


表2-2 結婚年㢼と各仮説との関係（現在年歯令：31-34歳層）

\begin{tabular}{|c|c|c|c|c|c|}
\hline \multicolumn{2}{|c|}{ 仮説 } & 25歳以下 & 26-28歳 & 29歳以上 & \multirow{5}{*}{$\begin{array}{l}p<.01 \\
x^{2}=14.91\end{array}$} \\
\hline $\begin{array}{l}\text { 職 } \\
\text { 業 }\end{array}$ & $\begin{array}{c}\text { 経営·専門・教育 }(\mathrm{n}=145) \\
\text { 事務・販売 }(\mathrm{n}=278) \\
\text { 派遣・バイト・無職 } \quad(\mathrm{n}=85)\end{array}$ & $\begin{array}{l}16.6 \\
29.9 \\
22.4\end{array}$ & $\begin{array}{l}53.8 \\
46.0 \\
38.8\end{array}$ & $\begin{array}{l}29.7 \\
24.1 \\
38.8\end{array}$ & \\
\hline $\begin{array}{l}\text { 居 } \\
\text { 住 } \\
\text { 形 } \\
\text { 態 }\end{array}$ & 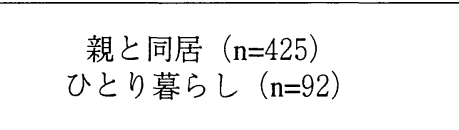 & $\begin{array}{l}26.1 \\
21.7\end{array}$ & $\begin{array}{l}47.5 \\
44.6\end{array}$ & $\begin{array}{l}26.4 \\
33.7\end{array}$ & \\
\hline $\begin{array}{l}\text { 育 } \\
\text { 休 } \\
\text { 制 } \\
\text { 度 }\end{array}$ & $\begin{array}{c}\text { 大企業・育休充実 }(\mathrm{n}=201) \\
\text { 中小・育休充実 }(\mathrm{n}=67) \\
\text { 制度充実していない }(\mathrm{n}=218)\end{array}$ & $\begin{array}{l}24.9 \\
14.9 \\
27.1\end{array}$ & $\begin{array}{l}47.3 \\
59.7 \\
44.0\end{array}$ & $\begin{array}{l}27.9 \\
25.4 \\
28.9\end{array}$ & \\
\hline 学 & $\begin{array}{l}\text { 職業系女子大 }(n=50) \\
\text { 教養系女子大 }(n=49) \\
\text { 中間系女子大 }(n=264) \\
\text { 共学大 }(n=154)\end{array}$ & $\begin{array}{l}26.0 \\
24.5 \\
24.6 \\
26.6\end{array}$ & $\begin{array}{l}48.0 \\
42.9 \\
51.1 \\
40.9\end{array}$ & $\begin{array}{l}26.0 \\
32.7 \\
24.2 \\
32.5\end{array}$ & \\
\hline
\end{tabular}

表2-3 結婚年齢と各仮説との関係（現在年齢：35-38歳層）

\begin{tabular}{|c|c|c|c|c|c|}
\hline \multicolumn{2}{|c|}{ 仮説 $\quad$ 結婚年齢 } & 25歳以下 & 26-28歳 & 29歳以上 & \multirow{3}{*}{$\begin{array}{l}* \\
x^{2}=11.71\end{array}$} \\
\hline $\begin{array}{l}\text { 職 } \\
\text { 業 }\end{array}$ & $\begin{array}{c}\text { 経営·専門 ·教育 }(\mathrm{n}=229) \\
\text { 事務・販売 }(\mathrm{n}=332) \\
\text { 派遣・バイト・無職 }(\mathrm{n}=135)\end{array}$ & $\begin{array}{l}25.8 \\
32.5 \\
23.0\end{array}$ & $\begin{array}{l}46.7 \\
38.6 \\
37.0\end{array}$ & $\begin{array}{l}27.5 \\
28.9 \\
40.0\end{array}$ & \\
\hline $\begin{array}{l}\text { 居 } \\
\text { 焦 } \\
\text { 態 }\end{array}$ & $\begin{array}{l}\text { 親と同居（n=571） } \\
\text { ひとり暮らし }(n=133)\end{array}$ & $\begin{array}{l}28.9 \\
27.8\end{array}$ & $\begin{array}{l}40.3 \\
43.6\end{array}$ & $\begin{array}{l}30.8 \\
28.6\end{array}$ & \\
\hline $\begin{array}{l}\text { 育 } \\
\text { 休 } \\
\text { 制 } \\
\text { 度 }\end{array}$ & $\begin{array}{c}\text { 大企業・育休充実 }(\mathrm{n}=229) \\
\text { 中小・育休充実 }(\mathrm{n}=87) \\
\text { 制度充実していない }(\mathrm{n}=354)\end{array}$ & $\begin{array}{l}26.2 \\
17.2 \\
31.9 \\
\end{array}$ & $\begin{array}{l}41.0 \\
40.2 \\
42.4 \\
\end{array}$ & $\begin{array}{l}32.8 \\
42.5 \\
25.7 \\
\end{array}$ & $\begin{array}{l}* \\
x^{2}=13.1\end{array}$ \\
\hline 㔜 & $\begin{array}{c}\text { 職業系女子大 }(n=79) \\
\text { 教養女子大 }(n=43) \\
\text { 中間系女子大 }(n=332) \\
\text { 共学大 }(n=251)\end{array}$ & $\begin{array}{l}24.1 \\
23.3 \\
29.8 \\
29.5\end{array}$ & $\begin{array}{l}50.6 \\
34.9 \\
45.8 \\
32.7\end{array}$ & $\begin{array}{l}25.3 \\
41.9 \\
24.4 \\
37.8\end{array}$ & $\begin{array}{l}* * \\
x^{2}=20.58\end{array}$ \\
\hline
\end{tabular}

以上の分析結果から、仮説は全て支持されなかった。

第 1 に、「専門職晚婚仮説」は、「経営・専門職」の結婚年齢が高いはずである。しかし、 28-30歳層は「職業」の説明力がなく、31-34歳層と35-38歳層の場合、「経営・専門職」は 26-28歳で結婚する者が多かった。31-34歳層と35-38歳層では、29歳以降に結婚する者が多 かったのは「派遣・無職」であった。

第 2 に、「パラサイト・シングル仮説」では、親と同居し、日常生活を親に依存する者 は晚婚のはずである。しかし、どの年齢層においても一貫して「居住形態」の説明力はな かった。 
第 3 に、「育児・休業制度仮説」では、「育児・休業制度」の充実は結婚を促進するはず である。しかし、31-34歳層では「育休制度」の説明力はなく、28-30歳層と35-38歳層でも 育児休業制度の充実は結婚年齢を低めていなかった。

第 4 に、「ジェンダー・トラック仮説」は、「職業系女子大学」出身者の結婚が遅く、 「教養系女子大学」出身者の結婚は早いはずである。しかし、28-30歳層と31-34歳層では 「大学」の説明力はなかった。35-38歳層では「職業系女子大学」出身者は26-28歳、「教養 系女子大学」出身者は29歳以降に結婚する者が多かった。

\section{2 結婚年齢と社会的・職業的自立との関係}

先の分析では、31-34歳層と35-38歳層において、「派遣・無職」の結婚年齢が高く、「職 業」が結婚年齢を説明する有力な要因と思われる。先行研究では、結婚後の雇用継続を求 める女性が増加していて、結婚後の雇用継続には職場でのキャリア形成の準備期間が必要 であるために、女性が晚婚化する（今田 1996）こと、高学歷女性は結婚前にキャリアを 積み上げるために結婚を遅らせる（大沢 1993）ことなどが説明されてきた。一方、結婚 後の就業意志が弱い者は晚婚であることも示される（阿部 1999）。また、経済的自立や 専門性に価值をおくフリーターは、フリーター期間を適職に就くための職業スキルを伸ば す期間と考える。親などへの依存性の高いフリーターは結婚までに自由にやりたいことを する期間と考えている（日本労働研究機構 2001）。

先行研究の知見から、本研究の「経営・専門職」は職業的キャリアを確立したため結婚 が早いと思われる。一方、「派遣・無職」は自分に合う仕事を探し、結婚よりは職業的自 立を優先させたいという意識や、社会的自立よりは自由にやりたいことをしたいという意 識が結婚年齢を高めた考えられる。

そこで、社会的・職業的自立意識の高低が結婚年齢に与える影響を検討するため、社会 的・職業的自立に関する主観的指標を設定した。はじめに、「経済的に自立していると思 う」「精神的に自立していると思う」「社会人として一人前だと思う」「社会的立場が確立 できている」「仕事に自信がもてるようになった」について、「あてはまる」から「あては まらない」までの 4 点尺度で質問した結果を用いる。これらの回答を主成分分析したとこ ろ、固有值 1 以上の主成分が 2 つ抽出され、全分散の $74 \%$ 説明された。第 1 主成分は 「経済的に自立していると思う」「精神的に自立していると思う」「社会人として一人前だ と思う」「社会的立場が確立できている」「仕事に自信がもてるようになった」に対して高 い負荷量を持ち、「社会的・職業的自立意識」の指標と解釈することができる。この第 1 主成分の主成分得点を「社会的・職業的自立」の尺度として用いる。

「社会的・職業的自立意識」が結婚年齢を高めているか低めているかを予測するロジス テック回帰分析を試みる。従属変数は、結婚年齢が28歳以下か、29歳以上か。独立変数は、 先の各仮説を検討した際の变数(14)（「職業」、「居住形態」「大学」など）と「社会的・職 業的自立意識」である。

年齢層別に分析した結果、28-30歳層は有意ではなかった。31-34歳層では、「派遣・無 職」であること、「社会的・職業的自立意識」が高いほど結婚年齢を高める方向に作用し ていた（表3-1）。35-38歳層では、「派遣・無職」であること、「大企業・制度充実」して いる場合、「中小企業・制度充実」している場合、「社会的・職業的自立意識」が高いほど 
結婚年齢を高め、「職業系女子大学」出身と「教養系女子大学」出身は結婚年齢を低めて いた（表3-2）。

表3-1＼cjkstart結婚年齢に関するロジスティック回帰分 析結果（現在年鈢：31-34歳層）

\begin{tabular}{|c|c|c|c|}
\hline & $\begin{array}{l}\text { ロジステイック } \\
\text { 回帰倸数 }\end{array}$ & $\begin{array}{l}\text { 有意 } \\
\text { 確率 }\end{array}$ & $\begin{array}{c}\text { オッズ } \\
\text { 比 }\end{array}$ \\
\hline 経営·専門·教育職 & 0.28 & & 1.32 \\
\hline 派遣・バイト・無職 & 1.05 & ** & 2.86 \\
\hline 居住形態 & 0.29 & & 1.34 \\
\hline 大企業・育休充実 & 0.04 & & 1.04 \\
\hline 中小・育休充実 & -0.17 & & 0.85 \\
\hline 職業系女子大 & -0.51 & & 0.60 \\
\hline 教養系女子大 & 0.19 & & 1.21 \\
\hline 中間系女子大 & -0.39 & & 0.68 \\
\hline 社会的·職業的自立因子 & 0.23 & $*$ & 1.26 \\
\hline-2 対数尤度 & 543.29 & & \\
\hline$x^{2}$ & 22.64 & & \\
\hline 自由度 & 9 & & \\
\hline 有意確率 & * & & \\
\hline
\end{tabular}

${ }^{*} \mathrm{p}<.05, * * * \mathrm{p}<.001$ 表3-2＼cjkstart結婚年歯に関するロジスティック回帰分 析結果（現在年齢：35-38歳層）

\begin{tabular}{|c|c|c|c|}
\hline & $\begin{array}{l}\text { ロジステイック } \\
\text { 回帰倸数 }\end{array}$ & $\begin{array}{l}\text { 有意 } \\
\text { 確率 }\end{array}$ & $\begin{array}{c}\text { オッズ } \\
\text { 比 }\end{array}$ \\
\hline 経営·専門·教育職 & -0.09 & & 0.91 \\
\hline 派遣・バイト·無職 & 0.61 & * & 1.84 \\
\hline 居住形態 & -0.23 & & 0.80 \\
\hline 大企業・育休充実 & 0.42 & $*$ & 1.52 \\
\hline 中小·育休充実 & 0.73 & $* *$ & 2.07 \\
\hline 職業系女子大 & -0.79 & * & 0.45 \\
\hline 教養系女子大 & 0.02 & & 1.02 \\
\hline 中間系女子大 & -0.51 & $*$ & 0.60 \\
\hline 社会的. 職業的自立因子 & 0.34 & $* * *$ & 1.40 \\
\hline-2 対数尤度 & 766.42 & & \\
\hline$x^{2}$ & 43.29 & & \\
\hline 自由度 & 9 & & \\
\hline 有意確率 & *** & & \\
\hline
\end{tabular}

${ }^{*} \mathrm{p}<.05,{ }^{* *} \mathrm{p}<.01,{ }^{* * *} \mathrm{p}<.001$

\section{3 「派遣・無職」で晚婚の社会的・職業的自立意識と結婚後の就業意志}

31-34歳層と35-38歳層では共通して、「派遣・無職」であること、「社会的・職業的自立 意識」が高いほど結婚年齢を高める方向に作用していた。31-34歳層と35-38歳層（以下、 31-38歳層）では、「派遣・無職」と「社会的・職業的自立意識」は結婚年齢を説明する有 力な仮説といえる。先行研究では、晚婚者は結婚後の就業継続を望むか否かによって未婚 時の「社会的・職業的自立意識」が異なっていた。31-38歳層のうち、29歳以降に結婚し た未婚時「派遣・無職」者のみを対象に、「社会的・職業的自立意識」の程度（低・中 · 高）と結婚後の就業意志との関係を検討する必要がある。

結婚後の就業意志を確かめるには、初職時と結婚時のライフコース展望に関する設問と 「結婚後、夫は外で働き、妻は家庭を守る方がよいかどうか」、「子どもが小さいうちは、 母親は仕事を持たず家にいる方がよいかどうか」をたずねた設問を用いる。初職時と結婚 時のライフコース展望ともに、「就業継続型」希望者に「社会的・職業的自立意識」の高 い者が多く、「退職型」希望者には「社会的・職業的自立意識」の低い者が多い（表4-1、 表4-2)。「結婚後、夫は外で働き、妻は家庭を守る方がよい」を否定する場合は「社会 的・職業的自立意識」の高い者が多い（表4-3)。一方、「結婚後、夫は外で働き、妻は家 庭を守る方がよい」を肯定する場合は「社会的・職業的自立意識」の低い者が多い。「子 どもが小さいうちは、母親は仕事を持たず家にいる方がよい」を肯定する者は「社会的・ 職業的自立意識」が低く、否定する者は「社会的・職業的自立意識」が高い（表4-4）。

以上から結婚後就業を望む場合に「社会的・職業的自立意識」が高く、結婚後の就業意 志が弱い場合に「社会的・職業的自立意識」が低いことが明らかになった。大卒女性の 
「派遣・無職」には結婚後の就業を希望する場合、未婚時に社会的・職業的立場を確立す るために結婚を遅らせる者、結婚後の就業意志が弱い場合はやりたいことを自由にやって 結婚を遅らせる者が存在する。

表4-1 晚婚「派遣・無職」者の「社会的・職業的自 立意識」と初職時ライフコース展望との関係 単位: \%

\begin{tabular}{|c|r|r|r|}
\hline ライフコース自立度望 & 自立低 & 自立中 & 自立高 \\
\hline 就業継続型 $(n=40)$ & 37.5 & 22.5 & 40.0 \\
再参入型 $(n=18)$ & 22.2 & 61.1 & 16.7 \\
退職型 $(n=20)$ & 50.0 & 30.0 & 20.0 \\
その他 $(n=8)$ & 33.3 & & 66.7 \\
\hline$p=0.017, x^{2}=15.33$ & & & \\
\hline
\end{tabular}

表4-2 晚婚「派遣・無職」者の「社会的・職業的自 立意識」と結婚時ライフコース展望との関係 単位: \%

\begin{tabular}{|c|r|r|r|}
\hline ライフコース自立度 & 自立低 & 自立中 & 自立高 \\
\hline 就業継続型 $(n=32)$ & 34.4 & 18.8 & 46.9 \\
再参入型 $(n=33)$ & 27.3 & 42.4 & 30.3 \\
退職型 $(n=12)$ & 66.7 & 25.0 & 8.3 \\
その他 $(n=7)$ & 42.9 & 42.9 & 14.3 \\
\hline
\end{tabular}

$\mathrm{p}=0.056, x^{2}=12.24$

就業継続型：「結婚せず仕事を一生続ける」「結婚するが子供はもたず仕事を一生続ける」、「結婚し子供をもつが、 仕事も一生続ける」

再参入型：「結婚し子供を持つが、結婚や出産の機会に退職し、子育て後に再び仕事を持つ」

退職型：「結婚し子供をもち、結婚や出産の機会に退職し、その後は仕事を持たない」

表4-3 晚婚「派遣・無職」者の「社会的・職業的自 立意識」と性別役割分業意識との関係

単位: \%

\begin{tabular}{|c|c|c|c|}
\hline 性別分業意識 自立度 & 自立低 & 自立中 & 自立高 \\
\hline あてはまる（n=27） & 51.9 & 33.3 & 14.8 \\
\hline あてはまらない（n=56） & 28.6 & 30.4 & 41.1 \\
\hline
\end{tabular}

$\mathrm{p}=0.036, x^{2}=6.64$

性別分業意識：「結婚後、夫は外で働き、妻は家庭 を守る方がよい」
表4-4 晚婚「派遣・無職」者の「社会的・職業的自 立意識」と子育て意識との関係

\begin{tabular}{|c|c|c|c|}
\hline 子育て意識 & 自立低 & 自立中 & 自立高 \\
\hline あてはまる（n=50） & 42.0 & 36.0 & 22.0 \\
\hline あてはまらない（n=34） & 29.4 & 23.5 & 47.1 \\
\hline
\end{tabular}

$\mathrm{p}=0.053, x^{2}=5.84$

子育て意識：「子供が小さいうちは、母親は仕事を 持たず家にいる方がよい」

\section{5.まとめと考察}

\section{1 まとめ}

本研究では、結婚年齢を説明する各仮説を年齢層別に検証し、以下を明らかにした。

第 1 に、「専門職晚婚仮説」では、「経営・専門職」の結婚年齢は高いはずである。しか し、28-30歳層においては「職業」の説明力はなく、31-34歳層と35-38歳層の場合、「経 営・専門職」は26-28歳で結婚する者が多かった。29歳以降の結婚には「派遣・無職」が 多かった。専門職晚婚仮説は支持されなかった。

第 2 に、「パラサイト・シングル仮説」では、親と同居し、日常生活を親に依存する者 は晚婚のはずである。しかし、一貫してどの年齢層においても「居住形態」の説明力はな く、パラサイト・シングル仮説は支持されなかった。

第 3 に、「育児・休業制度仮説」では、「育児・休業制度」の充実は結婚を促進させるは ずである。しかし、31-34歳層では「育休制度」の説明力はなく、28-30歳層と35-38歳層で も育児休業制度の充実は結婚年齢を低める方向に作用していなかった。すなわち、企業規 模にかかわらず、育览休業制度の充実は結婚年齢を低める方向に影響を与えていなかった。 
第 4 に、「ジェンダー・トラック仮説」は、「職業系女子大学」出身者の結婚が遅く、 「教養系女子大学」出身者の結婚は早いはずであった。しかし、28-30歳層と31-34歳層で は「大学」の説明力はなかった。35-38歳層では「職業系女子大学」出身者は26-28歳、 「教養系女子大学」出身者は29歳以降に結婚した者が多く、仮説とは異なる結果であった。

第 5 に、「派遣・無職」に晚婚者が多い要因を検討した。先行研究の知見から「派遣・ 無職」の晚婚者には職業的自立を優先させる者と社会的自立よりは自由にやりたいことを 優先させる者がいると考えられる。社会的・職業的自立意識に関する主観的指標として 「社会的・職業的自立意識」を設定し、「職業」や「居住形態」、「社会的・職業的自立意識」 などが結婚年齢を高めるか低めるかを予測するロジスティック回帰分析を行った。31-38 歳層において「派遣・無職」と「社会的・職業的自立意識」が結婚年齢を説明する重要な 変数であることが明らかになった。

第 6 に、晚婚者には結婚後の就業意志によって未婚時の「社会的・職業的自立意識」が 異なるという先行研究の知見に基ついて、「派遣・無職」者の結婚後の就業意志と「社会 的・職業的自立意識」との関係を検討した。未婚時「派遣・無職」者の結婚後の就業意志 が強い者は、職業的立場の確立を優先して結婚を遅らせ、結婚後の就業意志が弱い者は、 結婚まで自由にやりたいことをやるために結婚を遅らせることが明らかになった。

\section{2 考 察}

これまで女性の晚婚化に関する研究は、高学歴化による専門職や結婚前の親との同居な どが注目され、世代別結婚年齢と職業との関係は十分に検討されなかった。従来の研究に 対して本研究では、年齢層別に結婚年齢集団を分けて、結婚年齢と各仮説との関係を検討 し、31-34歳層と35-38歳層は未婚時に「派遣・無職」の場合に晚婚者が多いことが明らか になった。さらに、31-38歳層のうち、未婚時に「派遣・無職」で、結婚後の就業意志が 強い場合には職業的自立を優先させて晚婚になる者、結婚後の就業意志が弱く、自由にや りたいことをやって晚婚になる者が存在することを明らかにした。

「派遣・無職」のうち結婚後の就業意志が強く、社会的・職業的自立を優先して晚婚に なるという結果は、調査対象者が高階層の大卒女性であり高等教育を受けたことが反映し ていると思われる。これは、高等教育を通じて、調査対象者が業績主義的価值を内面化し ている結果とも考えられる。

一方、「経営・専門職」や「事務・販売職」の結婚が早い理由を考察すると、昇進など 目に見えて職階が上がるわけではなくても、責任ある業務をまかされたり、自分の判断を 必要とするような責任のある業務を行えることによると思われる。西川（2001）や冨田 （2001）も指摘するように、やりがいのある仕事、自分の考えを活かし、判断することが 必要な仕事に就いている場合、仕事で能力発揮できること、男女同じような仕事をしてい る職場にいることなどが女性の結婚と就業の両立には不可欠である。

女性の晚婚化傾向についてこれまでエンゼル・プランなどの政策が注目されてきた。し かし、本研究に関連して行ったインタビューでも、育児休業制度が充実していても、職場 環境や仕事内容などの要因で、実際に育児休業制度を利用できるとは限らないことは結婚 前からわかっていたと、全員が指摘していた。

今後の方策としては、安定した仕事に就いた場合に結婚が早く、未婚時に「派遣・無 
職」で結婚後の就業意志が強い場合に結婚が遅いという結果から、女性が安定した仕事に 就くための支援策や安定した仕事ができる職場環境の整備が必要である。

本研究の対象者は、両親とも高学歴で、比較的高階層の者が多かった。そのため、本研 究の結果は、高階層者の影響を反映していると思われる。今後はサンプルの幅を広げて、 高卒・短大卒女性などを含めた幅広い階層を対象にした調査を行い、女性の職業と結婚行 動との関係について検討していくことが課題である。

註

（1）ただし、岩澤の分析には、従業上の地位が使用され、職種についてはわからない。

（2）調査は、科学研究費基盤研究補助金（c）（研究代表者：岩木秀夫）の一環として実施されたもの であり、本稿はその成果の一部である。デー夕の使用については、研究代表者の許可を得た。

(3) 1 月調査は女子大学 3 校を対象に調査を行い、有効回収率 $36.0 \%$ （有効回収票は、既婚者 846 票、 未婚者 317 票）である。12月調査は女子大学 4 校と共学大学 10 校を対象に調査を行い、有効回収率 $23.1 \%$ (有効回収票は、既婚者548票、未婚者282票) である。本研究の対象者の平均初婚年踊や従業 上の地位・職種などは『第11回出生動向基本調查』と比較しても大きな違いは見られない。このこと から、本研究の結果は有効回答率の少なさの影響はないと考える。

1 月調查と 12 月調査はともに、大学卒業年度を統一した対象者に対して、初職や結婚時の職業など を中心に質問している。そのため、本研究の結果に対して調査時期のずれによる影響はない。

(4) 調査は、大学の卒業生名簿から等間隔に抽出した女性に、未婚者用と既婚者用の調査票を送付し、 未既婚により調査票を選択記入し、郵送で返送してもらう方法を採用した。

（5）地域によって平均初婚年齢が異り、平均初婚年齢の最も高い地域は首都圈である。そこで、首都圈 の四年制大学を卒業した女性を調査対象とした。

(6) 共学大学出身者の出身学部は、文学部、社会学部、経済学部、法学部などの人文・社会科学系とし た。夜間部（二部）出身者は対象から除外した。

（7）調査対象大学偏差值（代々木ゼミナール2001年ホームページ参照）は以下の通りである。職業系の A女子大学57-61、教養・職業系の中間的特徵をもつB女子大学52-57、C女子大学52-59、教養系の特徵 をもつD女子大学51、E女子大学49-53、F女子大学46-49、G女子大学45-49。共学大学は、a大学62-67、 b大学64、c大学62-66、d大学59-62、e大学54-56、f大学54-55、g大学49-56、h大学51-55、i大学51-54、j 大学45-50。大学の特徵は、中西（1998）を参考にした。

（8）国立社会保障・人口問題研究所『第11回出生動向基本調査』（1998年）によると、1987-1997年に結 婚した「大学以上」の学歴をもつ妻の平均初婚年齢。

（9）『第11回出生動向基本調査』（1998年）では、父と母それぞれの同別居が示されていたが、『第11回 出生動向基本調査』(1999年）では母親との同別居のみが示されていたため、母親との同別居のみが 示された結果を利用した。

(10) 官公庁、学校、1000人以上規模の企業とした。

(11) 999人以下規模の企業とした。

(12) 先行研究では、育児休業制度が実施されているか否かが結婚行動にどのような影響を与えるかが検 討されている。本研究では、育児休業制度が充実していない場合は、制度には期待ができないと思わ れるため、企業規模別にはしなかった。

(13) 以下の分析は、SPSS for Windowsを利用した。

(14)「職業」：(1)「経営·専門・教育職ダミー」(経営・専門・教育職 $=1$ 、その他 $=0$ )、(2)「派遣 · アルバイト・無職ダミー」（派遣・アルバイト・無職など $=1$ 、その他 $=0$ ）を設定した。基準は、 「事務・販売職」とした。

「居住形態」：「パラサイトダミー」(親と同居 $=1$ 、その他 $=0$ ) を設定した。

「育休制度」: (1)「大企業・制度充実ダミー」（大企業で制度が充実している場合＝1、その他= 
0 )、(2)「中小企業・制度充実ダミー」（中小企業で制度充実＝1、その他＝0）を設定した。基準は 「制度不足（充実していない）」。

「大学」: (1)「職業系女子大学ダミー」(職業系女子大学出身=1、その他=0)、(2)「教養系女子大 学ダミー」(教養系女子大学出身 $=1$ 、その他の大学 $=0$ )、(3)「中間系女子大学ダミ一」(中間系女子大学 出身=1、その他の大学 $=0$ ）を設定した。基準は、「共学大学出身」とした。

\section{文献}

阿部正浩 1999 「少子化社会における労働市場一女性の結婚と労働力供給の視点から一」『季刊社会保 障研究』34巻 4 号, 361-373頁。

阿藤誠 1991 「人口少産化の背景とその展望」『日本労働研究雑誌』No.381, 2-11頁。

1997 「少子化』に関するわが国の研究動向と政策的研究課題」『人口問題研究』第53巻4号, 1-14頁。

樋口美雄 1994 「育児休業制度の実証分析」社会保障研究所編『現代家族と社会保障』東京大学出版会,

181-204頁。

今田幸子 1996 「女子労働と就業継続」『日本労働研究雑誌』No.433, 37-48頁。

岩澤美帆 1998 「結婚·家族に関する妻の意識」国立社会保障・人口問題研究所編『平成 9 年日本人の 結婚と出産一第11回出生動向基本調査一』厚生統計協会, 48-55頁。

国立社会保障 ·人口問題研究所 1998 『平成 9 年日本人の結婚と出産一第11回出生動向基本調査—』

厚生統計協会。

— 1999 『平成 9 年独身青年層の結婚観と子供観一第11回出生動向基本調査一』厚生統計協会。 小島宏 1990 「晚婚化の傾向／シングルズの増加」『家族社会学研究』No.2, 10-23頁。

1994 「独身者・夫婦の融合データによる結婚と出生の分析」厚生省人口問題研究所編『独身 青年層の結婚観と子供観一第10回出生動向基本調査一』厚生統計協会, 95-102頁。

中西祐子 1998 『ジェンダー・トラック一青年期女性の進路形成と教育組織の社会学—』東洋館出版。

日本労働研究機構編 2001 『大都市の若者の就業行動と意識—広がるフリーター経験と共感一』調査 研究報告書No.146。

西川真規子 2001 「高学歴女性と継続就労一就労選考と就労行動の関係を探る—」脇坂・冨田編『大

卒女性の働き方』日本労㗢研究機構, 83-100頁。

大沢真知子 1993 『経済変化と女子労働』日本経済評論社。

労働省編 2000 『労働白書 (平成12年版)』日本労働研究機構。

滋野由紀子・大日康史 1998 「育児休業制度の女性の結婚と就業継続への影響」『日本労働研究雑誌』 №.459, 39-49頁。

渡邊吉利 1993 「夫婦の結婚に関する調査結果 (4) 職業と平均初婚年齢」厚生省人口問題研究所編

『平成 4 年日本人の結婚と出産』厚生統計協会, 4 頁。

渡辺秀樹 ·近藤博之 1990 「結婚と階層結合」岡本英雄 - 直井道子編『現代日本の階層構造(4)一女性 と社会階層—』東京大学出版会, 119-145頁。

冨田安信 2001 「外資系で働く、官公庁で働く一民間企業での働き方とくらべて一」脇坂・冨田編

『大卒女性の働き方』日本労働研究機構, 67-81頁。

山田昌弘 1996 『結婚の社会学一未婚化・晚婚化はつづくのか一』丸善。

— 1999 『パラサイト・シングルの時代』筑摩書房。

脇坂明 2001 「大卒女性の現状と雇用管理の変化一コース別管理とファミフレ一」脇坂・冨田編『大 卒女性の働き方』日本労働研究機構, 1-20頁。

（日本女子大学大学院·研究生 